\title{
Environmental influences on post-harvest natural regeneration of Pinus pinaster Ait. in Mediterranean forest stands submitted to the seed-tree selection method
}

\author{
Encarna Rodríguez-García ${ }^{1,2}$, Libertad Juez ${ }^{1,2}$ and Felipe Bravo ${ }^{1,2}$ \\ 1 Departamento de Producción Vegetal y Recursos Forestales. E.T.S. de Ingenierías Agrarias. \\ Universidad de Valladolid. Avenida de Madrid, 44. 34004 Palencia, Spain. Corresponding author e-mail \\ address: ergarcia@pvs.uva.es \\ ${ }^{2}$ Sustainable Forest Management Research Institute UVa-INIA. Avenida de Madrid, 44. 34004 Palencia, \\ Spain.
}

\begin{abstract}
Background: Research on natural regeneration is crucial for the development of sustainable forestry practices, in light of the global climate changes taking place. In this study one hundred and fifty-one plots were sampled in six Pinus pinaster stands that were naturally regenerated by the seed-tree method in Mediterranean forests in central Spain.

Objective: The objectives of the survey were to study the suitability of different forest stands designated for natural regeneration as well as to analyse seedling establishment and the relationship between regeneration and different site factors. Analysis of variance (ANOVA) and multivariate analysis with canonical ordination techniques were employed. Full and partial redundancy analyses (RDAs) on a correlation matrix were used to carry out a direct gradient analysis of regeneration density as a function of site factors.

Results: Nearly all stands presented seedling densities over 2000 seedlings/ha and were thus found to be suitable for natural regeneration of Pinus pinaster by the seed-tree selection method. Significant variables that best explained total seedling and viable seedling density were spring and autumn precipitation of the year prior to establishment, spring and summer precipitation of the year of establishment, and percentage cover of litter. There were no signs of competition between shrubs and seedlings, but a negative significant correlation with grass cover was observed. Pinus pinaster natural regeneration was successful with the seed-tree method, although it appeared to be highly dependent on climate and stand conditions.
\end{abstract}

Key words: Maritime pine/ Precipitation/ RDA/ Seedling dynamics/ Site factors

This is a pre-copyedited, author-produced PDF of an article published in 2010 in European Journal of Forest Research.

The final publication: Volume 129, Issue 6, pp 1119-1128 is available at Springer via: http://link.springer.com/article/10.1007/s10342-010-0399-7

An erratum to this article can be found at:

http://dx.doi.org/10.1007/s10342-010-0416-x 


\section{INTRODUCTION}

Understanding the natural regeneration of plant species is an important prerequisite for conservation and management (Guarigata and Pinard 1998). The natural regeneration of forest communities is a complex process driven by different factors and shaped by the ecological and demographic characteristics of the species, disturbance history and stochastic events (Paluch 2005). Regeneration involves many stages in the life cycle of plants, from the budding of flowers to the survival and recruitment of established seedlings (Madsen and Larsen 1997). The success of each stage, with the seed and seedling stages recognized as the most important (Houle 1996), depends in turn on the interactions of many site factors (Kitajima and Fenner 2000). Site factors define the habitat and can be considered as all physical and biotic factors that influence the survival and growth of seedlings (Matney and Hodges 1991). They include both climatic factors such as temperature, humidity and radiation regimes during the growing season, and soil factors such as soil moisture, depth of the humus layer and soil texture, which affect water and nutrient availability at the soil surface and in the soil horizon (Rojo and Montero 1996). Topography, which influences temperature and water regimes (Madsen and Larsen 1997), understory cover (Dobrowolska 1998; Kitzberger 2000) and the formation of a soil seed bank (Enrico et al. 2004) also significantly affect the establishment and survival of tree seedlings. The impact of herbivores (Paluch 2005), pathogens (Auspurguer 1983) and competition with grass (De Steven 1991) can hinder regeneration success.

Studies on the natural regeneration of Pinus pinaster Ait. in Mediterranean ecosystems have focused on post-fire aspects (Calvo et al. 2008; Fernandes and Rigolot 2008; Perula et al. 2003). However, the site factors that drive natural regeneration in silvicultural treatments are not well understood, even though this widespread conifer covers close to $1,200,000$ ha of the Iberian landscape, (Gil et al. 1990). Pinus pinaster can be divided into three groups (Baradat and Marpeau 1998): Atlantic (ssp. atlantica H. del Villar); European Mediterranean and Maghreb (both ssp. mesogeensis F. et Gaussen), and includes populations in central and southern Spain. The Iberian populations show elevated levels of genetic variability due to an important genotype by environment interaction that has enabled local adaptation to ecological conditions, resulting in 28 populations or provenances (Alía et al. 1996). Pinus pinaster is a primary colonizing species after disturbances occur and requires a high light regime to 
grow (Gil et al. 1990). It has enormous ecological plasticity, grows in a great range of soils and tolerates conditions varying from Mediterranean to Temperate-Oceanic climates (Blanco et al. 2001). Outside its natural range, this species is considered one of the most invasive plants in the world (Lowe et al. 2000). In light of this, information about its relationships with different environments and its recruitment process can be very useful for developing colonization models.

Few studies have characterised the effects of silvicultural treatments on the natural regeneration of Pinus pinaster and how environmental factors influence the process (González-Alday et al. 2008; Papanastasis et al. 1995; Rodríguez-García et al 2007; Varelides and Kritikos 1995). Seed or shelter tree systems have great potential for successful and inexpensive regeneration, but typically display large variations in natural regeneration. Although regeneration of Pinus pinaster with a seed or shelter tree system for natural regeneration can result in dense stands (Rodríguez et al. 2008; RodríguezGarcía et al. 2007), there are also several examples of poor regeneration success (Rodríguez et al. 2008). Natural regeneration attempts had to be abandoned in some harvested stands and replaced by planting or sowing because of unsatisfactory natural seedling establishment (Hyppönen et al. 2005). The key to fully unlocking the potential of this method is found in determining the suitability of sites for natural regeneration (Madsen and Larsen 1997). The effects of forest management on natural regeneration are poorly understood in the case of Pinus pinaster. Our hypothesis is that natural regeneration of Pinus pinaster using the seed-tree harvesting method can lead to successful natural regeneration in Mediterranean forests. However, stand suitability may vary depending on site factors and local climatic conditions. The objectives of this study were (1) to examine the suitability for natural regeneration of different forest stands that were subjected to the seed-tree harvesting method and (2) to analyse seedling establishment and the relationship between regeneration and different site factors. Fulfilment of these objectives should lead to an improved understanding of the ecology of the natural regeneration of Pinus pinaster and how environmental factors interact with and affect the seed-tree regeneration method in a Mediterranean area.

\section{MATERIAL AND METHODS}

\subsection{Study sites}

The study stands are located in Pinus pinaster forests in central Spain (Fig. 1). All stands are located in a sandy area. Stand 1 is located $\left(4^{\circ} 45^{\prime}-\mathrm{W}\right.$ and $\left.41^{\circ} 15^{\prime}-\mathrm{N}\right)$ in Olmedo 


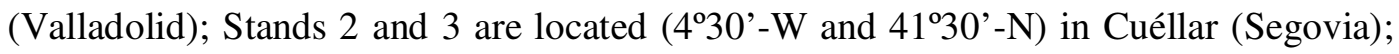
Stands 4, 5 and 6 are located $\left(2^{\circ} 39^{\prime}-2^{\circ} 55^{\prime}-\mathrm{W}\right.$ and $\left.41^{\circ} 30^{\prime}-41^{\circ} 33^{\prime}-\mathrm{N}\right)$ in the area of Almazán-Bayubas (Soria). The seed-tree harvesting method had been applied to all stands within a ten year period before sampling (Table 1), with no subsequent management or natural disturbance. No soil treatments were carried out and wood harvesting procedures did not differ among stands. In all stands, seed-tree selection was based on tree vigour, dominance and phenotype. Felled trees were trailed on the ground and removed from the stands, leaving harvest debris. The density of final shelter trees varied between 25 and 50 trees/ha.

The vegetation present at the sites mainly included shrubs such as Thymus mastichina L., Lavandula stoechas L., Cistus populifolius L. and Cistus laurifolius L. along with some woody species such as Juniperus thurifera L., Quercus ilex L. and Quercus faginea Lam. in stands with higher soil moisture. Pinus pinea L. trees were found in drier stands with higher soil sand content. The Mediterranean climate features cold winters and hot dry summers, and rainfall mainly occurs in spring and late autumn. Soils are predominantly Entisols (De La Rosa et al. 2001), and all were classified as acidic soils with a sandy texture.

\subsection{Sampling and database}

Sampling within the stands was conducted systematically using a 100 x $100 \mathrm{~m}$ grid (random start) and the Stocked Quadrant method (Mueller-Dombois and Ellenberg 1974). This method has been used previously in Mediterranean areas (GonzálezMartínez and Bravo 2001; Rodríguez-García et al. 2007). Circular plots with a $2.5 \mathrm{~m}$ radius were established in the grid intersections and then divided into four quadrants (Fig.1). With that radius, assuming a regular distribution pattern and a density close to 2000 trees $\mathrm{ha}^{-1}$, a quadrant size of $4.9 \mathrm{~m}^{2}$ was obtained, which corresponded to the space available for each hypothetical individual adult tree. A natural regeneration density greater than 2000 seedlings/ha has been observed for Pinus pinaster in many forest

stands (Rodríguez et al. 2008), and has been established as the minimum density required for natural regeneration to be considered successful (Matney and Hodges 1991). However, a density of between 1000 and 1500 viable trees/ha may be considered satisfactory in stands with abiotic stress. 


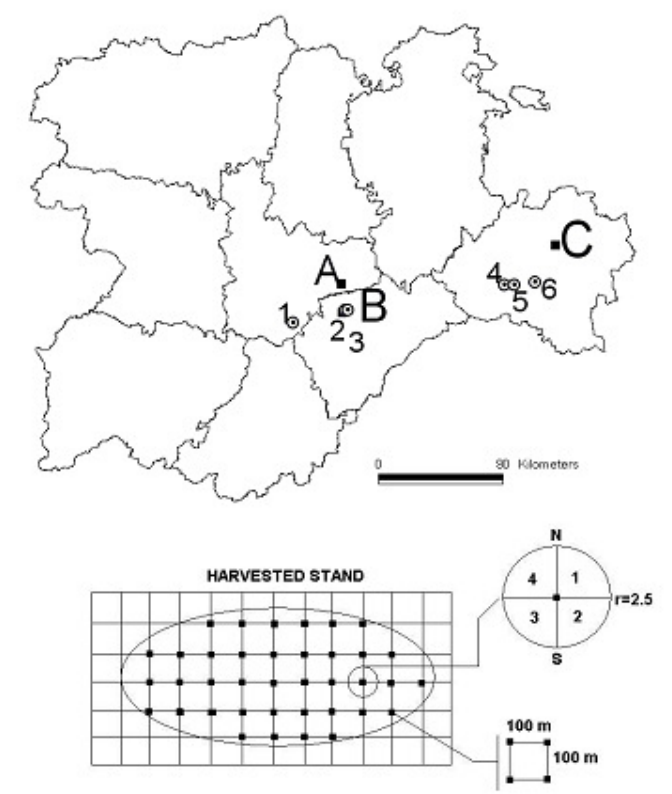

Figure 1. Location of the study stands (numbers) and meteorological stations (letters) used for climatic data, and schedule of the systematic sampling design.

A stem count of seedlings with a maximum dbh of $7.5 \mathrm{~cm}$ was performed within the plots. Height $(\mathrm{cm})$, basal diameter $(\mathrm{mm})$ at ground level, vigour state (undamaged or damaged by climatic and other conditions such as desiccation, grazing, or pathogens) and seedling social position (dominant or suppressed) with respect to other individuals of the same species or nearby shrubs were recorded for each seedling. A seedling was considered viable when it was rated as both undamaged and dominant. While we cannot assume that seedlings classified as non-viable will not eventually be established, their apparently low fitness for growth or survival implies that these seedlings are likely not be established or to be eliminated in new thinnings of the stands. Total density (TD) and viable density (VD) of seedlings ha ${ }^{-1}$ were then calculated for each stand (average of all plots) without considering different age groups. In plots where at least one healthy and dominant seedling was established, we used dummy variables (1/0) to analyse regeneration success by establishing the percentage of plots in each of three categories: 1) plots with 500 seedlings ha ${ }^{-1}$; 2) with 1000 seedlings ha ${ }^{-1}$ and 3) with 2000 seedlings $\mathrm{ha}^{-1}$. The average annual height increment (AAHI, $\mathrm{cm} /$ years) for Pinus pinaster seedlings was obtained for each stand, and a regeneration index (RI) was calculated using density per average height of seedlings $\left(\mathrm{N} \mathrm{ha}^{-1} * \mathrm{AH}\right)$. This index has been used 
before (Bucci and Borghetti 1997) and could be an easy tool for describing stand suitability for natural regeneration, because it links seedling height and density. Seedling age was estimated visually on site by counting the number of branch whorls. Recently germinated seedlings (from autumn or spring of the sampling year) were classified as 0 years old.

Table 1. Main characteristics of Pinus pinaster study stands submitted to the seed-tree selection method in six forests of central Spain.

\begin{tabular}{|c|c|c|c|c|c|c|c|c|c|c|}
\hline Stand & $\mathrm{N}$ & $\overline{\mathrm{BA}}$ & DSS & $\overline{\mathrm{SA}}$ & ST & $\overline{\text { Alt }}$ & $\overline{\mathrm{T}}$ & 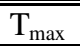 & $\overline{T_{\min }}$ & $\overline{\mathrm{P}}$ \\
\hline 1 & 22 & $8.8 \pm 2.9$ & $20.7 \pm 32.9$ & 2007 & 6 & $750.9 \pm 14.8$ & 13.8 & 17.7 & 4.4 & 440 \\
\hline 2 & 25 & $9.9 \pm 3.7$ & $9.9 \pm 9.0$ & 2005 & 4 & $788.8 \pm 12.4$ & 12.1 & 18.9 & 5.4 & 493 \\
\hline 3 & 29 & $6.5 \pm 5.7$ & $10.0 \pm 17.9$ & 2005 & 3 & $795.8 \pm 39.4$ & 12.1 & 18.9 & 5.4 & 493 \\
\hline 4 & 30 & $5.9 \pm 2.9$ & $9.9 \pm 6.0$ & 2004 & $5-7-9$ & $990.4 \pm 29.9$ & 11.5 & 17.8 & 5.1 & 450 \\
\hline 5 & 16 & $1.6 \pm 1.2$ & $21.6 \pm 11.1$ & 2004 & $3-4-5$ & $840.4 \pm 18.9$ & 11.5 & 17.8 & 5.1 & 450 \\
\hline 6 & 29 & $4.3 \pm 4.6$ & $16.1 \pm 18.5$ & 2004 & $5-6-8$ & $1009.9 \pm 26.1$ & 11.5 & 17.8 & 5.1 & 450 \\
\hline
\end{tabular}

Values given are mean \pm standard deviation; N: number of plots per stand; BA: Basal area of shelter trees $\left(\mathrm{m}^{2} \mathrm{ha}^{-1}\right)$; DSS: distance to the nearest seed source $(\mathrm{m})$; SA: sampling year; ST: Stand age (years between harvesting and sampling); Alt: meters above sea level; $\mathrm{T}$ : average monthly temperature $\left({ }^{\circ} \mathrm{C}\right) ; \mathrm{T}_{\max }$ : average monthly maximum temperature; $\mathrm{T}_{\min }$ : average monthly minimum temperature $\left({ }^{\circ} \mathrm{C}\right)$; average monthly maximum temperature $\left({ }^{\circ} \mathrm{C}\right) ; \mathrm{P}$ : average monthly precipitation $(\mathrm{mm})$.

Basal area $\left(\mathrm{BA}, \mathrm{m}^{2} \mathrm{ha}^{-1}\right)$, and the nearest seed-source distance (DSS, m) were recorded in the plots, together with the number of stumps and cones on the plot soil surface. Site factors studied in relation to understory vegetation included the percentage cover of moss (Mosscov), grass (Grasscov), and total shrubs (Shrcov) per plot, as well as the percentage cover of harvest debris (loggcov) and litter. All coverage percentages were measured visually to the nearest 5\%. The height of shrubs (Shrh, $\mathrm{cm})$ and grass (Grassh, cm) measured from their geometrical centre, and of harvest debris, were measured with a tape to the nearest $0.5 \mathrm{~cm}$ in each plot. Topographical measurements included altitude (masl), slope (\%), aspect and percentage cover of surface stones (\%).

A soil sample was obtained from $20 \mathrm{~cm}$ below the soil surface (GonzálezMartínez et al. 2001) in a random sub-sample of $10 \%$ of the plots in each stand. Local soil maps consulted before selecting the sampling plots (De la Rosa et al. 2001) confirmed that the soils were homogenous within each stand. Soil samples were analysed to determine the percentage of sand, silt and clay (USDA 1951), the percentage of carbonate and organic matter (carbon method), and the concentration of phosphorus (ppm) (Olsen method). Concentrations of potassium (ppm), calcium, magnesium and sodium (meq/100 g) were determined after extraction using $1 \mathrm{~N}$ 
ammonium acetate; $\mathrm{pH}$ (suspension 1: 2.5) and electrical conductivity $(\mathrm{dSm} / \mathrm{m})$ were also determined. Laboratory soil analyses were carried out following standard procedures for agricultural soil research (MAPA 1994).

Regeneration establishment dynamics after harvest were examined according to the age class distribution of the monitored seedlings. Modal, median and maximum seedling ages were calculated in each stand in order to identify the main establishment years and advance regeneration (seedlings established before harvesting). The median age was used for all analyses. Precipitation and temperature variables were used to characterize the local climate of the stands. Mean annual precipitation (mm) and monthly minimum and maximum temperatures $\left({ }^{\circ} \mathrm{C}\right)$ were calculated with series of data from 1960 (Stand 1), 1975 (Stands 2 and 3) and 1989 (Stands 4, 5 and 6) to the sampling year. Precipitation in each season (autumn, spring, summer and winter), of the year preceding establishment (after calculating age-class distributions) was taken into account. Weather stations were located near the sampled stands and at a similar altitude (Figure 1).

\subsection{Statistical analysis}

First of all, suitability for natural regeneration was characterized in each stand in terms of total (TD) and viable (VD) seedling density, age structure, percentage of stocking, height increment and RI. Due to the lack of normality in the variables considered to describe regeneration, a non-parametric ANOVA test (Kruskal-Wallis) was used to analyse statistical differences among stands. Differences among levels were adjusted with probabilities of error to $\alpha=0.05$. Spearman's correlation coefficients between density data and site factors, at a significance level of $95 \%(p \leq 0.05)$, were also calculated. The SPSS ${ }^{\circledR} 15.0$ package was used for descriptive examination and frequency graphs.

Since the stands had been disturbed and sampled in different years, the relative importance of stand age (ST) and sampling year (SA) on the regeneration data variation (TD and VD) was analysed before searching for the explanatory site factors (E) that best explained regeneration distribution. A Detrended Correspondence Analysis (DCA) revealed a linear environmental response (length of the axes $<2$ each), so the data were submitted to a Redundancy Analysis (RDA), (Ter Braak 1995). RDA is a direct gradient analysis technique, or the canonical form of PCA, which was invented by Rao (1964). It selects the linear combination of environmental variables that best explains the species 
composition (in our case TD and VD) and gives the smallest total residual sum of squares (Ter Braak 1995). Full and partial RDAs were then used to separate the pure ST and SA effects from the site factors $(\mathrm{E})$ by means of a variation partitioning method (Borcard et al. 1992; Qinghong and Brakenhielm 1995; Park 2001). For the analysis, a partial RDA was run three times using TD and VD as response variables throughout the whole procedure. E, ST and SA were each used as the explanatory variable and the other two as covariables. For each combination, four runs of RDA were obtained for variance partitioning (Borcard et al. 1992; Qhinghon and Brakenhielm 1995). The significance of the total canonical variation in each partial RDA was tested with 999 Monte-Carlo permutations of the reduced model in the CANOCO 4.5 package. After deducting all sources of covariance, a partial RDA was performed using $\mathrm{E}$ as the environmental matrix, with ST and SA as covariables. Then, a forward stepwise method was used to select ordination variables, with independent variables added in decreasing order of the total explained variance (Wimberly and Spies 2001). The relationship of each independent variable to the density variables was tested against a null hypothesis of random association using a permutation test (Monte Carlo) with 999 unrestricted permutations under a full model $(p<0.05)$. Species data (TD and VD) were submitted to logarithmic transformation.

\section{RESULTS}

\subsection{Stand suitability for natural regeneration}

Regeneration in all sampled stands was classified as successful, except for Stand 1

(Table 2). Seedling total density $\left(X^{2}=21.20\right.$, d.f. $\left.=5, p<0.001\right)$ and viable density $\left(X^{2}=27.62\right.$, d.f. $\left.=5, p<0.00\right)$ differed among stands. The lowest density of viable seedlings occurred in Stand 1. Age frequencies varied by stands (Figure 2). Stands 2 and 3 presented a large amount of advance regeneration (65\%), while most of the seedlings monitored in Stand 1 were young (86\%). A high density of 3 to 5 year-old seedlings was observed in Stands 4 and 5, whereas a high density of 0 to 2 year-old seedlings was found in Stand 6. 

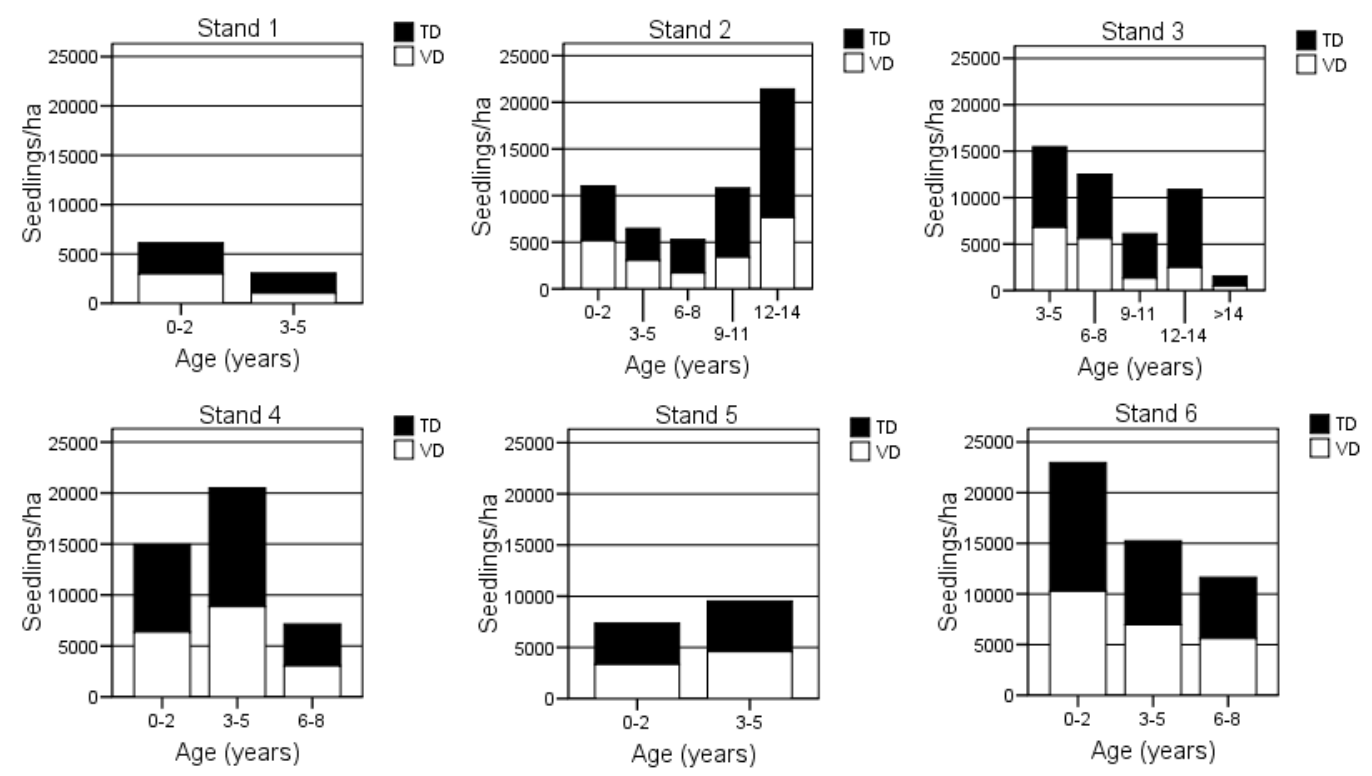

Figure 2. Pinus pinaster seedling densities in six stands harvested with the seed-tree method in forests of central Spain, according to seedling age-class distribution patterns.

After seed-tree harvesting, seedling establishment dynamics showed a different pattern in each stand (Figure 3). Seedling density had increased in all stands, thus confirming natural regeneration. The frequency patterns show continuous recruitment, but with regeneration pulses over time. The overall percentage of plots per stand with at least one viable seedling (500 seedlings $\mathrm{ha}^{-1}$ ) was very high (Table 2), but the percentage decreased as the density required increased. In Stand 6, 70\% of the plots presented a VD over 2000 seedlings ha ${ }^{-1}$, followed in decreasing order by Stands 2, 5, 4, 3 and 1.

The average annual height increment (AAHI) of the seedlings differed among stands $\left(X^{2}=53.71\right.$, d.f. $\left.=5, p=0.000\right)$, and the highest value was observed for Stand 4. The RI also differed significantly among stands $\left(X^{2}=42.76\right.$ d.f. $\left.=5, p=0.000\right)$, with the highest value for Stand 3 (Table 2). The regeneration ranking among stands was different using this index rather than TD or VD, due to the differences in height increment. 

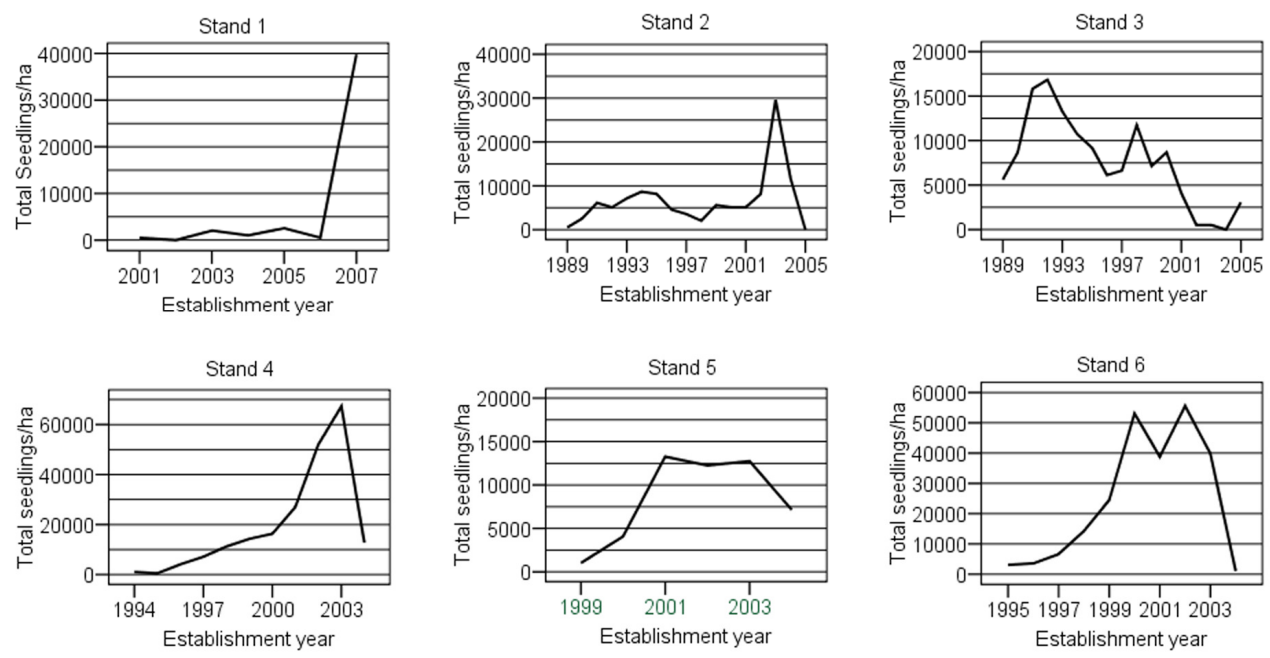

Figure 3. Pinus pinaster total seedling establishment per year after regeneration by the seed tree method, deducted from the median seedling age per stand, in six stands in forests of central Spain. 
Table 2. Total (TD) and viable (VD) seedling density, regeneration index (RI), annual average height increment (AAHI), and percentage of plots per stand with 500 viable seedlings ha ${ }^{-1}, 1000$ viable seedlings ha ${ }^{-1}$, and over 2000 seedlings ha ${ }^{-1}$ in six Pinus pinaster stands in forests of central Spain. Values given are mean \pm standard deviation.

\begin{tabular}{|c|c|c|c|c|c|c|c|c|c|}
\hline \multirow[t]{2}{*}{ Stand } & \multirow[t]{2}{*}{$\mathrm{N}$} & \multirow{2}{*}{$\begin{array}{c}\text { TD } \\
\left(\text { seedlings ha }{ }^{-1}\right)\end{array}$} & \multirow{2}{*}{$\begin{array}{c}\text { VD } \\
\left(\text { seedlings ha }{ }^{-1}\right)\end{array}$} & \multirow{2}{*}{$\begin{array}{c}\mathrm{RI} \\
(\text { seedlings ha } \\
\end{array}$} & \multirow[t]{2}{*}{$\mathrm{N}$} & \multirow{2}{*}{$\begin{array}{c}\text { AAHI } \\
\left(\mathrm{cm} \mathrm{year}^{-1}\right)\end{array}$} & \multicolumn{3}{|l|}{$\%$ Plots } \\
\hline & & & & & & & $500 \mathrm{ha}^{-1}$ & $1000 \mathrm{ha}^{-1}$ & $2000 \mathrm{ha}^{-1}$ \\
\hline 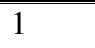 & 22 & $2210.39 \pm 2786$ & $1971.24 \pm 2640$ & $11960.42 \pm 23576$ & 22 & $8.79 \pm 3.95$ & 72 & 59 & 24 \\
\hline 2 & 25 & $5040.82 \pm 5782$ & $3346.94 \pm 3778$ & $144495.5 \pm 223497$ & 21 & $4.29 \pm 2.80$ & 84 & 76 & 56 \\
\hline 3 & 29 & $5190.01 \pm 8976$ & $2234.34 \pm 4484$ & $680495.80 \pm 1992854$ & 23 & $12.74 \pm 29.37$ & 58 & 38 & 27 \\
\hline 4 & 30 & $7448.98 \pm 8295$ & $5612.25 \pm 6383$ & $372354.60 \pm 510002$ & 22 & $17.43 \pm 3.32$ & 70 & 70 & 47 \\
\hline 5 & 16 & $3188.78 \pm 3472$ & $2742.35 \pm 3105$ & $79646.01 \pm 105539$ & 8 & $12.08 \pm 2.60$ & 75 & 62.5 & 50 \\
\hline 6 & 29 & $8954.96 \pm 7424$ & $7529.91 \pm 5687$ & $473449.00 \pm 422482$ & 29 & $15.16 \pm 4.93$ & 100 & 97 & 76 \\
\hline
\end{tabular}

$\mathrm{N}$ : number of plots used in the analysis. 


\subsection{Site factors driving natural regeneration}

Spearman analyses showed significant and positive correlations (only variables with $r \geq 0.40$ are commented) between seedling height and shrub height ( $p<0.01)$, but a negative correlation $(p<0.01)$ between total seedling density (TD), seedling height and grass cover $(p<0.01)$. A positive correlation was found between TD, VD, seedling height and calcium concentration in the soil $(p<0.01)$. Sodium concentration was negatively correlated with VD $(p<0.01)$. VD and seedling height were positively correlated with stand altitude $(p<0.01)$, while summer precipitation in the year of seedling establishment was positively correlated with seedling height $(p<0.05)$.

Multivariate analysis carried out with full and partial RDAs indicated that stand age and sampling year exerted some influence, but their effects on the total canonical variation of the regeneration data was not considered significant. Stand age (ST) described up to $1.7 \%(F=1.351 ; p=0.25)$, while sampling year $(\mathrm{SA})$ described up to $0.7 \%(F=3.00$; $p=0.60)$. Site factors significantly influenced the canonical variation of the regeneration data $(F=11.44 ; p=0.002)$, and explained up to $64.8 \%$ of variance. After removing the influence of ST and SA (included as covariables in the RDA), the significant variables obtained using forward stepwise selection were spring $(F=234.76 ; p=0.002)$ and autumn $(F=9.16 ; p=0.004)$ precipitation in the year prior to establishment, spring $(F=35.59$; $p=0.002)$ and summer $(F=3.86 ; p=0.042)$ precipitation in the year of establishment, and percentage cover of litter $(F=3.82 ; p=0.004)$. The correlation between these variables and the first two RDA axes is shown in Table 3. RDA axis 1 (Fig. 4) mainly suggests a decreasing drought gradient, confirming that there was more precipitation available during spring and autumn. RDA axis 2 , which explained only $1 \%$ of the total variance, was correlated (0.19) with harvest debris cover (loggcov).

Table 3. Correlations of the significant environmental variables $(\mathrm{p}<0.05)$ with the first two RDA axes, and stand age and sampling year as covariables.

\begin{tabular}{lccccc}
\hline \hline Variable & PspA & PautA & Psp0 & Psum0 & Litter \\
\hline \hline Axis 1 & -0.81 & -0.73 & -0.70 & -0.52 & -0.19 \\
Axis 2 & 0.07 & 0.04 & 0.08 & 0.02 & -0.04 \\
\hline \hline
\end{tabular}

PspA and PautA are spring and autumn precipitation in $\mathrm{mm}$ in the year prior to seedling establishment; Psp0 and Psum0 are spring and summer precipitation in $\mathrm{mm}$ in the year of seedling establishment; Litter is the percentage of litter over the soil surface. 


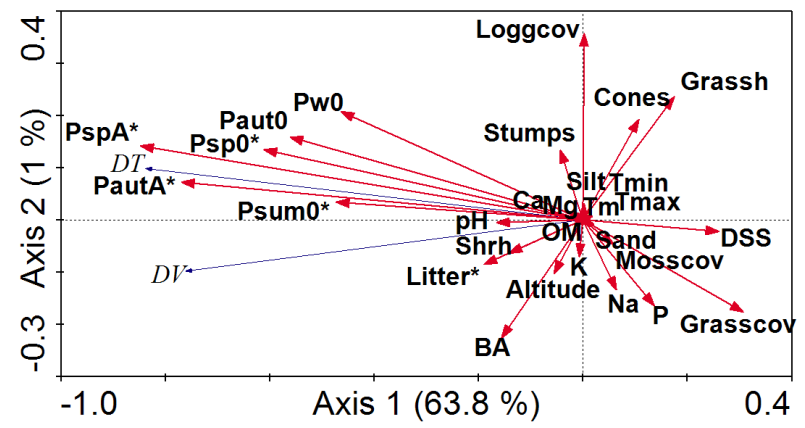

Figure 4. Species-environment biplot of RDA axes 1 and 2 after the removal of ST (stand age or years since harvesting) and SA (sampling year) covariance. Species codes are TD (total seedling density per stand) and VD (viable seedling density per stand). Site factors are PspA: spring precipitation in the year prior to establishment; PautA: autumn precipitation in the year prior to establishment; Psp0: spring precipitation in the year of establishment; Pw0: winter precipitation in the year of establishment; Paut0: autumn precipitation in the year of establishment; Psum0: summer precipitation in the current year of establishment; Loggcov: percentage coverage of harvest debris; stumps: average number of stumps per plot; cones: average number of cones over the plot soil surface; Tmin: mean monthly minimum temperature; Tmax: mean monthly maximum temperature; Tm; mean monthly temperature; Altitude: meters above sea level; Sand: percentage of sand; Silt: percentage of silt; Ca: Calcium concentration; Mg: Magnesium concentration; Na: Sodium concentration; K: Potassium concentration; OM: organic matter concentration; Litter: percentage cover of litter over the soil surface; DSS: distance to nearest seed source; Mosscov: percentage cover of moss; Grasscov: percentage cover of grass; Grassh: average height of grass; Shrh: average height of shrubs; BA: basal area of the shelter-trees. 'Edaphic properties' refers to the upper $20 \mathrm{~cm}$ of the soil layer. Significant variables $(p<0.05)$ are shown with an asterisk. 
Table 4. Edaphic properties at $20 \mathrm{~cm}$ depth in six Pinus pinaster stands in forests of central Spain.

\begin{tabular}{lcccccc}
\hline \hline \multicolumn{7}{c}{ Stand } \\
\hline \hline Variable & 1 & 2 & 3 & 4 & 5 & 6 \\
\hline $\mathrm{P}$ & $4.58 \pm 4.28$ & $1.06 \pm 1.92$ & $3.62 \pm 3.56$ & $4.4 \pm 0$ & - & $39.86 \pm 6.83 \mathrm{c}$ \\
$\mathrm{K}$ & $29.94 \pm 2.02 \mathrm{a}$ & $17.10 \pm 3.64 \mathrm{~b}$ & $21.73 \pm 5.93 \mathrm{~b}$ & $45.70 \pm 16.13 \mathrm{c}$ & $55.6 \pm 3.41 \mathrm{~d}$ & $39.23 \mathrm{c}$ \\
$\mathrm{Ca}$ & $0.96 \pm 0.01 \mathrm{a}$ & $1.24 \pm 0.17 \mathrm{a}$ & $1.34 \pm 0.50 \mathrm{a}$ & $2.4 \pm 0.83 \mathrm{~b}$ & $2.95 \pm 1.0 \mathrm{~b}$ & $3.64 \pm 1.23 \mathrm{c}$ \\
$\mathrm{Mg}$ & $0.32 \pm 0.03 \mathrm{a}$ & $0.25 \pm 0.03 \mathrm{a}$ & $0.26 \pm 0.08 \mathrm{a}$ & $0.36 \pm 0.14 \mathrm{ac}$ & $0.52 \pm 0.15 \mathrm{~b}$ & $0.45 \pm 0.26 \mathrm{bc}$ \\
$\mathrm{Na}$ & $0.02 \pm 0.0 \mathrm{a}$ & $0.02 \pm 0.0 \mathrm{ab}$ & $0.01 \pm 0.0 \mathrm{c}$ & $0.03 \pm 0.01 \mathrm{~b}$ & $0.01 \pm 0.0 \mathrm{~b}$ & $0.01 \pm 0.0 \mathrm{~b}$ \\
$\mathrm{OM}$ & $0.34 \pm 0.03 \mathrm{a}$ & $0.33 \pm 0.1 \mathrm{a}$ & $0.62 \pm 0.11 \mathrm{a}$ & $1.23 \pm 0.74 \mathrm{~b}$ & $1.35 \pm 0.33 \mathrm{~b}$ & $2.28 \pm 1.0 \mathrm{c}$ \\
$\mathrm{EC}$ & $0.02 \pm 0 \mathrm{a}$ & $0.02 \pm 0 \mathrm{a}$ & $0.03 \pm 0 \mathrm{a}$ & $0.05 \pm 0.01 \mathrm{~b}$ & $0.02 \pm 0.02 \mathrm{a}$ & $0.03 \pm 0.21 \mathrm{a}$ \\
$\mathrm{pH}$ & $6.26 \pm 0.06 \mathrm{a}$ & $6.18 \pm 0.07 \mathrm{ab}$ & $5.99 \pm 0.13 \mathrm{c}$ & $6.07 \pm 0.13 \mathrm{bc}$ & $6.51 \pm 0.11 \mathrm{~d}$ & $6.46 \pm 0.21 \mathrm{~d}$ \\
Sand & $90.03 \pm 0.51 \mathrm{a}$ & $90.03 \pm 0.51 \mathrm{~b}$ & $93.51 \pm 0.19 \mathrm{~b}$ & $87.10 \pm 5.99 \mathrm{c}$ & $81.50 \pm 0.13 \mathrm{~d}$ & $82.67 \pm 2.44 \mathrm{~d}$ \\
$\mathrm{Clay}$ & $5.79 \pm 2.54 \mathrm{a}$ & $4.28 \pm 0.44 \mathrm{ab}$ & $3.80 \pm 0.84 \mathrm{~b}$ & $1.7 \pm 0.47 \mathrm{c}$ & $2.5 \pm 0.52 \mathrm{c}$ & $2.37 \pm 0.49 \mathrm{c}$ \\
Silt & $6 \pm 0.00 \mathrm{a}$ & $1.72 \pm 0.84 \mathrm{~b}$ & $2.69 \pm 0.81 \mathrm{~b}$ & $13.20 \pm 5.93 \mathrm{c}$ & $13.0 \pm 2.07 \mathrm{c}$ & $14.95 \pm 2.61 \mathrm{c}$ \\
\hline \hline
\end{tabular}

Values given are mean \pm standard deviation. Values for P concentration in Stands 5 and 6 were not available. Units of variables are commented in the text. Different letters indicate significant differences $(p<0.05)$.P: phosphorous; K: potassium; Ca: calcium; Mg: magnesium; Na: sodium; OM: organic matter; EC: electrical conductivity; pH: soil ph; Sand, Clay and Silt: percentage of soil particles by size. 
Table 5. Vegetation and microsite properties in six Pinus pinaster stands in forests of central Spain.

\begin{tabular}{lcccccc}
\hline \hline \multicolumn{7}{c}{ Stand } \\
\hline \hline Variable & 1 & 2 & 3 & 4 & 5 & 6 \\
\hline Shrcov & $6.77 \pm 19.92$ & $2.84 \pm 6.71$ & $7.20 \pm 11.44$ & $19.03 \pm 14.84$ & $1.69 \pm 5.06$ & $23.69 \pm 15.69$ \\
Shrh & $6.34 \pm 12.55$ & $13.08 \pm 19.93$ & $25.10 \pm 28.29$ & $34.05 \pm 22.31$ & $4.06 \pm 9.17$ & $55.04 \pm 23.04$ \\
Grasscov & $58.18 \pm 26.88$ & $47.80 \pm 34.82$ & $24.66 \pm 27.19$ & $22.33 \pm 29.76$ & $50.63 \pm 35.58$ & $10.07 \pm 19.65$ \\
Grassh & $9.61 \pm 13.84$ & $20.16 \pm 11.59$ & $15.27 \pm 10.65$ & $9.73 \pm 13.20$ & $7.26 \pm 1.91$ & $11.76 \pm 17.61$ \\
Mosscov & $15.54 \pm 20.16$ & $8.56 \pm 15.89$ & $49.55 \pm 34.50$ & $7.01 \pm 12.22$ & $1.88 \pm 7.5$ & $2.24 \pm 7.86$ \\
Litter & $51.18 \pm 32.29$ & $26.40 \pm 29.09$ & $30.66 \pm 37.53$ & $25.50 \pm 25.34$ & $21.88 \pm 18.52$ & $27.41 \pm 31.72$ \\
Loggcov & $7.18 \pm 10.63$ & $13.04 \pm 21.35$ & $22.24 \pm 25.99$ & $18.76 \pm 18.98$ & $20.0 \pm 8.16$ & $42.81 \pm 25.09$ \\
Loggh & $5.15 \pm 7.52$ & $4.92 \pm 2.64$ & $5.69 \pm 3.79$ & $20.0 \pm 8.16$ & - & - \\
Stones & 0 & 0 & 0 & $11.83 \pm 18.87$ & $4.38 \pm 13.15$ & $3.62 \pm 8.75$ \\
\hline \hline
\end{tabular}

Values given are mean \pm standard deviation. Units of variables are commented in the text. Shrcov: percent coverage of shrub, Shrh: shrub height; Grasscov: percent coverage of grasses; Grassh: grass height; Mosscov: percent coverage of moss; Litter: percent coverage of litter over the soil surface; Loggcov: percent coverage of harvest debris; Loogh: harvest debris height; Stones: percent coverage of stones over the soil surface. 



\subsection{DISCUSSION}

The results of this study indicate the driving factors for natural regeneration of Pinus pinaster in Mediterranean forest stands submitted to seed-tree selection method. Even though recruitment was continuous, some pronounced peaks were observed (Fig. 3 ) every two to three years, indicating regeneration pulses over time. This dynamic may result from the Pinus pinaster reproductive cycle, in which seeds are formed in spring, ripen in autumn of their second year, and are dispersed in autumn and spring of the third year (Ceballos 1979).

Seed tree harvesting promoted natural regeneration in all stands, but regeneration analysis showed significant differences among the stands. This indicates that natural regeneration is dependent on local-site factors. Regeneration can be considered successful according the established requirements in all stands except Stand 1. These results reveal the suitability of all stands studied, except Stand 1, for natural regeneration of Pinus pinaster in Mediterranean areas and the advantage of using the shelter-tree method for the natural regeneration of this species. The lower seedling density in Stand 1 may be due to lower precipitation and higher average temperature in the area, and the large distance between seedlings and adult trees (DSS or distance to seed source), which could imply greater radiation and hydric stress. High seedling densities after seed tree harvest have been reported by other authors for this species (Rodríguez-García et al. 2007). Post-fire natural regeneration studies of Pinus pinaster also indicate high seedling densities after fire (e.g. Calvo et al. 2008). Thus, Pinus pinaster natural regeneration is generally good in the Mediterranean forests evaluated, although highly dependent on local climate and stand conditions. The lack of suitability of Stand 1, the great heterogeneity in seedling density and annual overall height increment among the stands seems to be due to differences in topographic, soil and understory properties, with climate as the key factor. On a landscape scale, a water availability gradient presented the major limiting factor for the regeneration success of Pinus pinaster; particularly spring and autumn precipitation in the year prior to establishment, which is related to seed formation, and spring and summer precipitation in the establishment year, which is related to germination and seedling survival. This has a spatial component that is reflected by regional differences in precipitation regimes, and a temporal component that follows the typical annual climatic fluctuations of Mediterranean areas. 
Climatic sensitivity of pines and natural recruitment has been well documented for other species such as Pinus ponderosa Dougl. ex Laws. A strong association appears between episodic recruitment and years associated with El Niño events, when spring and autumn moisture availability is high (League and Veblen 2006). A positive local and regional influence of climate on the radial growth of Pinus pinaster was identified by Bogino and Bravo (2008). Their results indicate that the radial growth of Pinus pinaster is positively correlated with precipitation prior to and during the growing season, as well as with summer precipitation before the growing season. Our results support their findings and suggest that Pinus pinaster could be a good candidate for studying-modelling the effect of global climate changes on the dynamics of Mediterranean forest stands (Bogino and Bravo 2008).

An increase in extremes was detected at both tails of the rainfall distribution curve in many Mediterranean regions (Alpert et al. 2002; Köchy 2008). A relation between $E l$ Niño events and rainfall anomalies in Europe was also found, but with some time-lag between them. Since low precipitation in the Iberian Peninsula is related to ENSO and NAO indexes (Esteban-Parra et al. 1998), studying El Niño events could be useful in operational forestry to program optimal harvest moments in the Mediterranean area. Local climate and site factors such as soil texture, which influences the availability of pulse-delivered rainfall (Noy-Meir 1973), may also affect the early regeneration stages of Pinus pinaster. Butcher (1977) found soil moisture to be the most limiting factor affecting growth in Australian Pinus pinaster plantations. This reinforces our results, which may be useful for developing management operations in places where this species is not considered autochthonous.

Finally, correlations between regeneration and other stand and microsite variables such as litter reinforce the idea of natural regeneration as a multi-factor dependent process. Litter probably acts as mulch (author's observation), which may enhance the survival, growth or fitness of seedlings by increasing the available soil moisture or by protecting soil from erosion, reducing water-loss and absorbing thermal oscillations (Rojo and Montero 1996). Our results also suggest that shrub cover did not compete with pine seedlings, which supports the results provided by Rodríguez-García et al. (2007) and Calvo et al. (2008). The fact that water availability may limit natural regeneration does not contradict this apparently positive relationship with shrub cover; in hydric stressed systems processes of facilitation may be more frequent than those of 
competition with neighbours (Bertness and Callaway 1994). However, grasses appeared to have a negative effect on seedling density and height.

\section{CONCLUSIONS}

There is a major lack of understanding regarding environmental influences on the natural regeneration and early establishment dynamics of post-seed tree harvest Pinus pinaster in Mediterranean areas. Most studies have analysed post-fire aspects, so efforts must be made to investigate and model the natural regeneration of this species as it relates to local management operations and site factors.

Our findings show that the seed-tree regeneration method is adequate for obtaining successful natural regeneration (densities over 2000 seedlings $\mathrm{ha}^{-1}$ ) of Pinus pinaster in Mediterranean forests. However, other parameters such as the regeneration index and percentage of plots with different stocking, should be used to characterise regeneration success. Our results also indicate a significant relationship between precipitation or water availability during spring, autumn and summer, the percentage cover of litter, and seedling density. Although further research should be carried out to corroborate these results, natural regeneration of Pinus pinaster seems to be sensitive to climate change and should be considered as a good candidate for exploring Mediterranean forest dynamics and species distribution shifts.

\section{ACKNOWLEDGEMENTS}

We thank two anonymous referees and the editor for their valuable comments on the initial version of the manuscript. We are grateful to the Ministerio de Ciencia $e$ Innovación for financial support for projects AGL2001-1780 and AGL2004-07094CO2-O2, and for grant BES-2005-7498. We thank the Spanish Meteorology Agency (AEMET), which facilitated climatic data, and V. Pando for his comments on the statistical analysis. We also thank Dr. G. Gratzer, Dr. J. Reque and B. Guerra for their valuable comments and are grateful to C. Ordóñez and A. de Lucas for field assistance.

\section{REFERENCES}

Alía R, Martín S, De Miguel J et al (1996) Regiones de procedencia de Pinus pinaster Aiton. Cátedra de Anatomía, Fisiología y Genética de la E.T.S.I de Montes. Madrid, Área de Selvicultura y Mejora. INIA-CESEFOR

Alpert P, Ben-Gai T, Baharad A, et al (2002) The paradoxical increase of Mediterranean extreme daily rainfall in spite of decrease in total values. Geophysical Research Letters 29:311-314 
Auspurguer C (1983) Seed dispersal of the tropical tree Platypodium elegans, and the escape of its seedlings from fungal pathogens. J Ecol 71:759-771

Baradat P, Marpeau-Bezard A (1988) Le pin maritime Pinus pinaster Ait. Biologie et genetique des terpenes pour la connaisance et l'ameloriation del l'espèce. Universitté Bourdeaux, Bourdeaux

Bertness M, Callaway R (1994) Positive interactions in communities. Trends in Ecology and Evolution 5:191-193

Blanco E, Casado González MA, Costa Tenorio M et al (2001) Los Bosques Ibéricos. Una interpretación geobotánica. Planeta, Barcelona

Bogino SM, Bravo F (2008) Growth response of Pinus pinaster Ait. to climatic variables in central Spanish forests. Ann For Sci 65:506-518. doi:10.1051/forest:2008025

Borcard D, Legendre P, Drapeau P (1992) Partialling out the spatial component of ecological variation. Ecology 73:1045-1055

Bucci G, Borguetti M (1997) Understory vegetation as a useful predictor of natural regeneration and canopy dynamics in Pinus sylvestris forests in Italy. Acta Ecologica 18(4):485-501

Butcher TB (1977) Impact of moisture relationships on the management of Pinus pinaster Ait. plantations in western Australia. For Ecol Manag 1:97-107

Calvo L, Santalla L, Valbuena L et al (2008) Post-fire natural regeneration of a Pinus pinaster forest in NW Spain. Plant Ecol 197:81-90

Ceballos L, Ruiz de la Torre J (1979) Árboles y Arbustos de la España Peninsular. Fundación Conde del Valle de Salazar, Madrid

De La Rosa D, Mayol F, Fernández M et al (2001) Seis.net. Sistema Español de Información de suelos en Internet http://www.irnase.csic.es/users/microleis/seistnet.htm

De Esteven D (1991) Experiments on mechanisms of tree establishment in old-field succession seedling survival and growth. Ecology 72:1076-1088

Dobrowolska D (1998) Structure of silver fir (Abies alba Mill.), natural regeneration in the Jata reserve in Poland. For Ecol Manag 110:237-247

Esteban-Parra MJ, Rodrigo FS, Castro-Díez Y (1998) Spatial and temporal patterns of precipitation in Spain for the period 1880-1992. Int J Climatol 18:1557-1574

Enrico L, Funes G, Cabido M (2004) Regeneration of Polylepis australis BIT. in the mountains of central Argentina. For Ecol Manag 190:301-309

Fernandes PM, Rigolot E (2007) The fire ecology and management of Pinus pinaster Ait. For Ecol Manag 241:1-13

Gil L, Gordo J, Catalán G, Pardos JA (1990) Pinus pinaster Aiton en el paisaje vegetal de la Península Ibérica. Ecologia 1:469-495 
González-Alday J, Martínez-Ruiz C, Bravo F (2008) Evaluating different harvest intensities over understory plant diversity and pine seedlings in a Pinus pinaster Ait. natural stand of Spain. Plant Ecol. doi:10.1007/s11258-008-9490-2

González-Martínez SC, Bravo F (2001) Density and population structure of the natural regeneration of Scots pine (Pinus sylvestris L.) in the High Ebro Basin (Northern Spain). Ann For Sci 58:277-288

Guarigata MR, Pinard MA (1998) Ecological knowledge of regeneration from seed in neotropical forest trees: implications for natural forest management. For Ecol Manag 112:87-99

Houle G (1996) Environmental filters and seedling recruitment on a coastal dune in subarctic Quebec (Canada). Can J Botany 74:1507-1513

Hyppönen M, Alenius V, Valkonen S (2005) Models for the establishment and height development of naturally regenerated Pinus sylvestris in Finnish Lapland. Scand J For Res 20:347-357

Keane RE, Austin M, Field C et al (2001) Tree mortality in gap models: application to climatic change. Climate Change 51:509-540

Kitajima K, Fenner M (2000) Ecology of seedling regeneration. In: Fenner M (ed) Seeds: the ecology of regeneration in plant communities. CAB International, Wallingford, UK

Kitzberger T, Steinaker D, Veblen T (2000) Effects of climatic variability on facilitation of tree establishment in northern Patagonia. Ecology 81(7):1914-1924

Köchy M (2008) Effects of simulated daily precipitation patterns on annual plant populations depend on life stage and climatic region. BMC Ecology 8:4. http://www.biomedcentral.com/1472-6785/8/4

League K, Veble T (2006) Climatic variability and episodic Pinus ponderosa establishment along the forest-grassland ecotones of Colorado. For Ecol Manag 228:98107.doi:10.1016/j.foreco.2006.02.030

Lowe S, Browne M, Boudjelas S et al (2000) 100 of the World's worst invasive alien species. A selection from the Global Invasive Database. In: The invasive Species Specialist Group (ISSG). A specialist group of the Species Survival Commission (SSC) of the World Conservation Union (IUCN), pp 12

Madsen P, Larsen JB (1997) Natural regeneration of beech (Fagus sylvatica L.) with respect to canopy density, soil moisture and soil carbon content. For Ecol Manag 97:95-105

MAPA (1994) Ministerio de Agricultura, Pesca y Alimentación. Métodos oficiales de análisis. Tomo III. Edita MAP, Madrid

Matney DT, Hodges DJ (1991) Evaluating regeneration success. In: Duryea ML, Dougherty PM (ed) Forest Regeneration Manual. Kluwer Academic, Dondrecht 
Mueller-Dombois D, Ellenberg H (1974) Measuring Species Quantities. In: Mueller-Dombois (ed) Aims and Methods of Vegetation Ecology. The Blackburn Press, pp 67-92

Noy-Meir L (1973) Desert Ecosystems: environment and producers. Ann Rev Ecol Syst 4:505521

Paluch J (2005) The influence of the spatial pattern on forest floor vegetation and silver fir (Abies alba Mill.) regeneration in uneven-aged forest. For Ecol Manag 205:283-298

Papanastasis V, Koukoura Z, Alifragis D, Makedos I (1995) Effects of thinning, fertilization and sheep grazing on the understory vegetation of Pinus pinaster plantations. For Ecol Manag 77:181-189

Park AD (2001) Environmental influences on post-harvest natural regeneration in Mexican pine-oak forests. For Ecol Manag 144:213-228

Perula VG, Cerrillo RMN, Rebollo PF et al (2003) Postfire regeneration of Pinus pinea L. and Pinus pinaster Ait. in Andalucia (Spain). Environ Manag 31:86-99

Quinghon L, Brekenhielm S (1995) A statistical approach to decompose ecological variation. Water, Air and Soil Pollution 85:1587-1592

Rao CR (1964) Linear statistical interpretation of principal component analysis in applied research. Sankhya A26:329-358

Rodríguez R, Serrada R, Lucas JA et al (2008) Selvicultura de Pinus pinaster Ait. subsp. mesogeensis Fieschi \& Gaussen. In Serrada R et al (ed) Compendio de Selvicultura aplicada en España, Madrid, pp 399-430

Rodríguez-García E, Juez L, Bravo F (2007) Análisis de la regeneración natural de Pinus pinaster Ait. en los arenales de Almazán-Bayubas (Soria, España). Invst Agrar: Sist Recur For 16(1):25-38

Rojo A, Montero G (1996) El pino silvestre en la Sierra de Guadarrama. Madrid

Ter Braak CJF (1995) Ordination. In: Jongman RHG, Ter Braak CJ, Van Tongeren OFR (ed) Data analysis in community landscape ecology. Cambridge University Press. United Kingdom

USDA (1951) Soil Survey Manual. In: Bureau of Plant Industry, Soils and Agriculture Engineering. US Department of Agriculture, Washington

Varelides C, Kritikos T (1995) Effect of site preparation intensity and fertilization on Pinus pinaster survival and height growth on three sites in northern Greece. For Ecol Manag 73:111-115

Wimberly MC, Spies TA (2001) Influences of environment and disturbance of forest patterns in coastal Oregon watersheds. Ecology 82(5):1443-1459 